\title{
Maxillary teeth in sperm whales, Physeter macrocephalus (Cetacea: Physeteridae)
}

\author{
TOLEDO, G. A. C. and LANGGUTH, A.* \\ Departamento de Sistemática e Ecologia, Universidade Federal da Paraíba - UFPB, \\ Campus Universitário I, Cidade Universitária, s/n, CEP 58059-900, João Pessoa, PB, Brazil \\ *E-mail: boninomvd@hotmail.com
}

\begin{abstract}
Sperm whales, Physeter macrocephalus Linnaeus, 1758, have 18 to 28 pairs of well developed conical mandibular teeth, but maxillary teeth are vestigial and supposedly rare. The aim of this study is to report a new case of erupted maxillary teeth in P. macrocephalus, the first description for Brazil. On 29 October 2008 a female sperm whale was found stranded in Campina's Beach ( $\left.06^{\circ} 46^{\prime} \mathrm{S}, 34^{\circ} 55^{\prime} \mathrm{W}\right)$, Paraíba state, northeastern Brazil. Inspection on the gums revealed three upper teeth on the right maxilla, corresponded to mandibular teeth 9 to 11 in a rostrocaudal sequence. The maxillary teeth were nearly straight, strongly worn in the tip and had no pulp cavity remaining. Most literature states that maxillary teeth are absent or rarely present, somewhat questionable, since other authors never failed to expose them by an incision in the gum. Data show that upper teeth have been overlooked, and its real frequency can only be determined by thorough dissections. This is important, since the study of maxillary teeth can provide information about evolution, functional morphology and age determination in sperm whales.
\end{abstract}

Keywords: Brazil, odontoceti, osteology, stranded, upper teeth.

\section{Introduction}

Sperm whales, Physeter macrocephalus Linnaeus, 1758, have 18 to 28 pairs of well developed conical teeth in the mandible, and when the mouth is closed, the apex of each tooth fits into a corresponding conical pit in the soft tissues of the upper jaw (RICE, 1989; JEFFERSON, LEATHERWOOD and WEBBER, 1993; CARWARDINE, 2002; REEVES, STEWART, CLAPHAM et al., 2002; WHITEHEAD, 2009). Despite being considered functional, mandibular teeth do not seem to be necessary for feeding, as they do not erupt until near puberty (at about eight years of age), and even some mature specimens were caught with no erupted teeth (RICE, 1989; WHITEHEAD, 2009).

Maxillary teeth are vestigial and supposedly rare in sperm whales (RICE, 1989; GIBBS and KIRK, 2001; JEFFERSON, WEBBER and PITMAN, 2008; WHITEHEAD, 2009). The occurrence of these teeth has been reported by authors who performed detailed dissections, since they usually are not superficial (FLOWER, 1869; BOSCHMA, 1938; MATTHEWS, 1938; OMURA, 1950; CLARKE, 1956; CLARKE, AGUAYO and PALIZA, 1968; GIBBS and KIRK, 2001; PIMPER, GOODALL, GIBBONS et al., 2008). One to 15 small maxillary teeth on each side of the jaw, larger and more numerous in males than in females have been reported (MATTHEWS, 1938; OMURA, 1950; CLARKE, 1956; CLARKE, AGUAYO and PALIZA, 1968; PIMPER, GOODALL, GIBBONS et al., 2008). According to Clarke, Aguayo and Paliza (1968), upper teeth do not erupt until males reached a length of $10 \mathrm{~m}$ and females reached $9 \mathrm{~m}$, with the numbers of erupted teeth thereafter increasing with body length.

In Brazil, sperm whales were commercially caught between 1952 and 1980 (TOLEDO and LANGGUTH, 2009) and have been frequently stranded over the years (CASTELLO and PIÑERO, 1974; RAMOS, SICILIANO, BOROBIA et al., 2001; MEIRELLES, MONTEIRO-NETO, MARTINS et al., 2009; SANTOS, SICILIANO, VICENTE et al., 2010), however there are no details on upper teeth. The aim of this study is to report a new case of erupted maxillary teeth in P. macrocephalus.

\section{Case report}

On 29 October 2008 a female sperm whale of $9.5 \mathrm{~m}$ total length was found stranded in Campina's Beach (06 $\left.46^{\prime} \mathrm{S}, 34^{\circ} 55^{\prime} \mathrm{W}\right)$, Paraíba state, northeastern Brazil (Figure 1). Standard measurements and necropsy procedures were performed by the authors at the beach, following stranding protocol (GERACI and LOUNSBURY, 2005).

Inspection of the gums revealed both mandibular and maxillary teeth. These were collected and still kept in Mammals' Collection of Universidade Federal da Paraíba, catalogue number UFPB 6000.

The specimen had 19 mandibular teeth on each side. The apex of these fitted into a corresponding pit in the maxilla. Inspection revealed three upper teeth on the right maxilla, each having erupted through the base of a separate pit. The teeth corresponded to mandibular teeth 9 to 11 in a rostrocaudal sequence (Figure 2). Each tooth lay against the lateral wall of the pit and the crowns of all three upper teeth surpassed the line of the gum surface for 1.2-1.5 mm. All maxillary teeth were nearly straight, strongly worn in the tip, and had no pulp cavity remaining (Figure 3 ). These teeth had, from first to last, $42.4,45.3$ and $47.7 \mathrm{~mm}$ of total length, and a maximum diameter of $11.5,15.7$ and $13.8 \mathrm{~mm}$, respectively. 


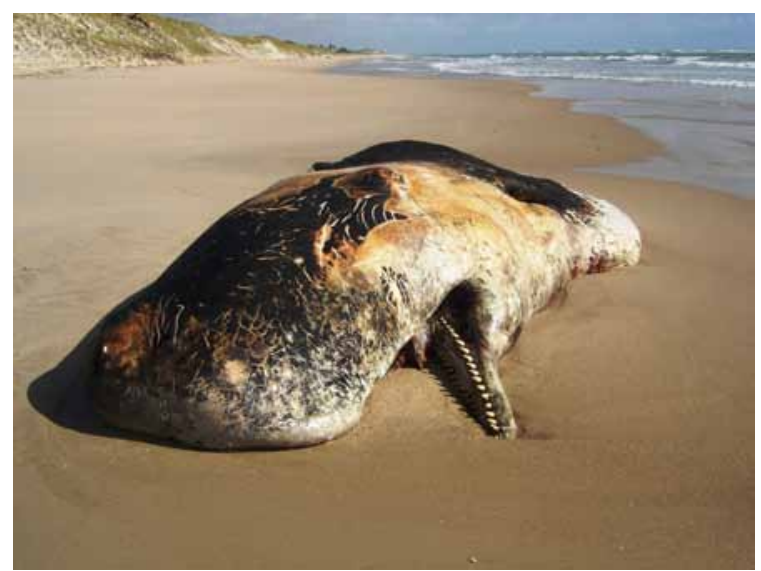

Figure 1. Studied female sperm whale, Physeter macrocephalus, stranded in Campina's Beach ( $\left.06^{\circ} 46^{\prime} \mathrm{S}, 34^{\circ} 55^{\prime} \mathrm{W}\right)$, Paraíba state, northeastern Brazil.

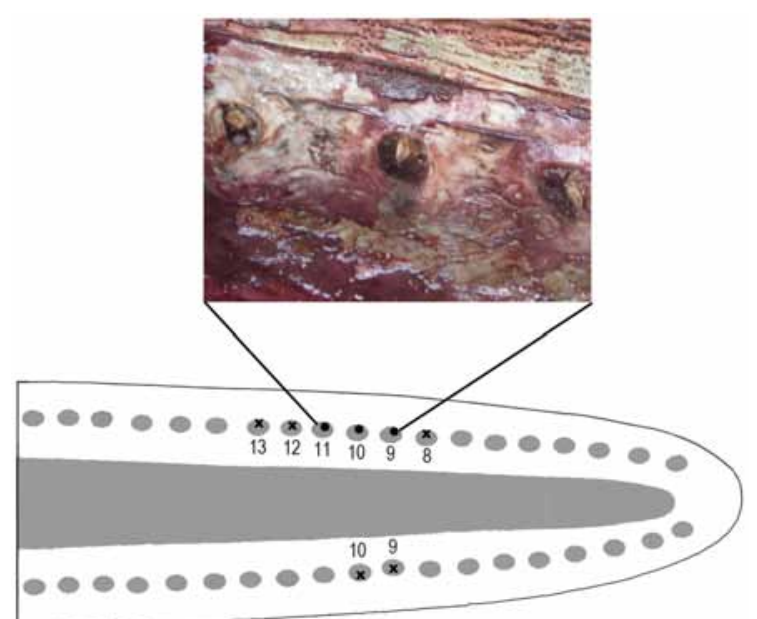

Figure 2. Ventral view of upper jaw of sperm whale, Physeter macrocephalus, showing regular pits, position of the three maxillary teeth (black circles) and locations of the probably missing maxillary teeth (black $\mathrm{x}$ ). Above, view of the gum with three erupted teeth.
Manual palpation of the remaining pits of the upper jaw did not reveal any further teeth, however subsequent examination revealed that six mandibular teeth on the right side (8-13 pits) and two mandibular teeth on the left side (9-10 pits) had worn tips due to abrasion on the lower tooth (Figure 3 ). This is a strong evidence for the presence of more upper teeth, but they probably were lost during the dissection.

\section{Discussion}

This is the first description of erupted maxillary teeth for sperm whales in Brazil. Ramos, Siciliano, Borobia et al. (2001) successfully estimated the age of a $12 \mathrm{~m}$ male sperm whale stranded in Rio de Janeiro using a maxillary tooth (MN 54999), but they did not provide any details about this tooth. Given the unworn tip, the tooth shown by Ramos, Siciliano, Borobia et al. (2001) certainly had not been erupted through the gum.

The filled pulp cavity of the maxillary teeth and the total length of $9.5 \mathrm{~m}$ suggest that the animal was sexually mature and had more than 10 years old (NISHIWAKI, HIBIYA and OHSUMI, 1958; BEST, CANHAM and MACLEOD, 1984). According Nishiwaki, Hibiya and Ohsumi (1958), the maxillary teeth are quite useful for age determination in sperm whales, especially unerupted ones and for individuals that have worn mandibular teeth.

Both curved and straight maxillary teeth, with wear produced by contact with mandibular teeth, have been previously described (FLOWER, 1869; BOSCHMA, 1938; MATTHEWS, 1938; CLARKE, 1956; CLARKE, AGUAYO and PALIZA, 1968; GIBBS and KIRK, 2001). However, unlike our record, Gibbs and Kirk (2001) observed that each upper tooth was placed into the medial wall of the pit suggesting that the position is variable.

The rarity of maxillary teeth in sperm whales is somewhat questionable. Most authors state that these teeth are absent or rarely present in sperm whales (RICE, 1989; JEFFERSON, LEATHERWOOD and WEBBER, 1993; CARWARDINE, 2002; REEVES, STEWART, CLAPHAM et al., 2002; JEFFERSON,
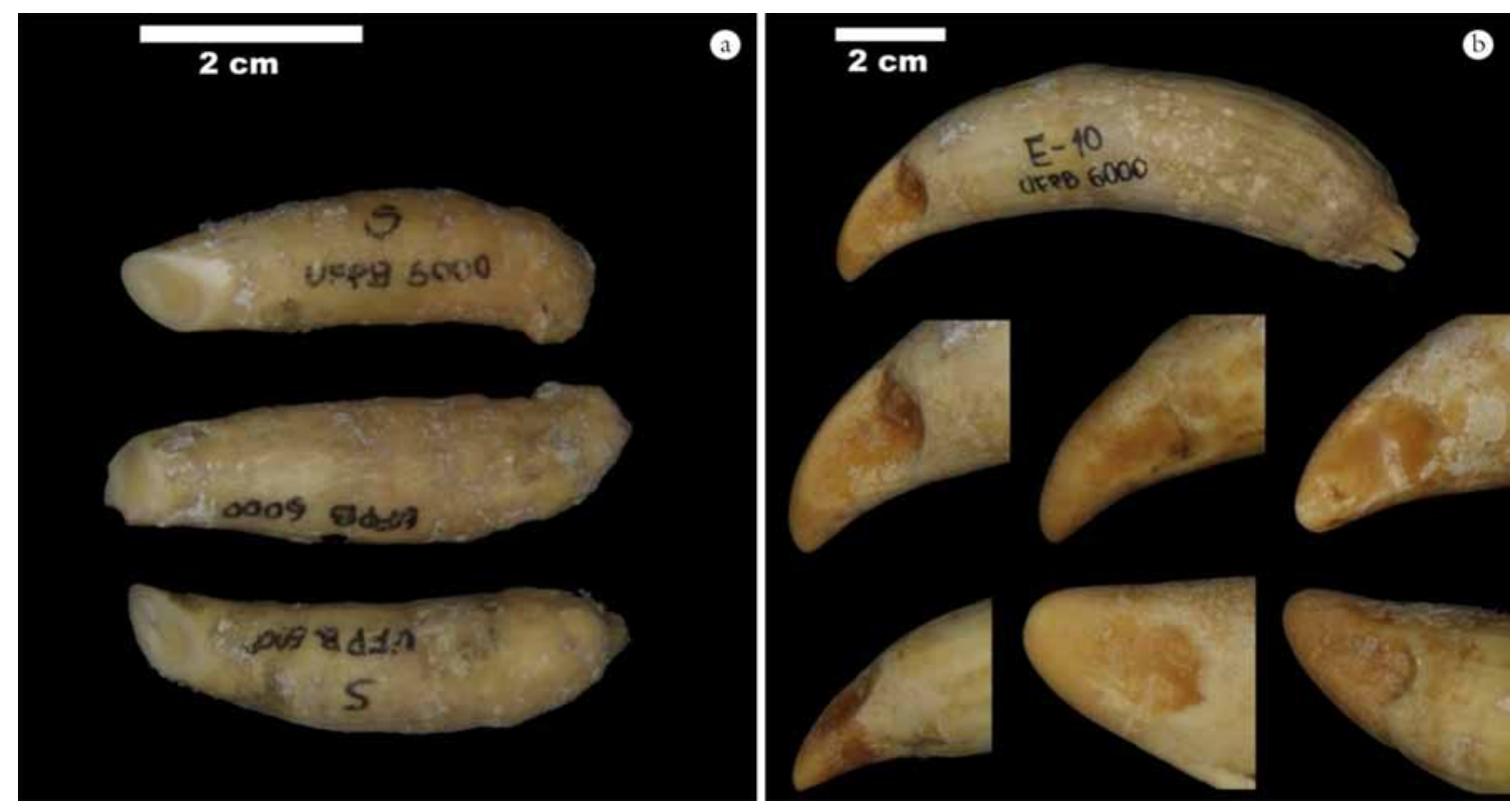

Figure 3. Maxillary teeth (a) and mandibular wear teeth (b) found in the sperm whale, stranded in Campina's Beach, northeastern Brazil. 
TOLEDO, G. A. C. and LANGGUTH, A.

Table 1. Sperm whales with maxillary teeth stranded in Tierra del Fuego, Argentina (source: PIMPER, GOODALL, GIBBONS et al., 2008). RNP = R. Natalie P. Goodall collection, Museo Acatushún, Ushuaia, Tierra del Fuego, Argentina.

\begin{tabular}{cccccc}
\hline Record number & Sex & $\begin{array}{c}\text { Total length } \\
(\mathbf{m})\end{array}$ & GLGs & $\begin{array}{c}\text { Teeth } \\
\text { (upper left) }\end{array}$ & $\begin{array}{c}\text { Teeth } \\
\text { (upper right) }\end{array}$ \\
\hline RNP 834 & M & 9.35 & 20 & 2 & 4 \\
RNP 841 & M & 10.9 & $20+$ & 5 & 2 \\
RNP 681 & M & 11.1 & $16+$ & 0 & 5 \\
RNP 844 & M & 11.2 & $19+$ & 1 & 0 \\
RNP 847 & M & 12.9 & $20+$ & 2 & 0 \\
RNP 1046 & M & 12.6 & - & 11 & 11 \\
RNP 1145 & M & 14.4 & - & 1 & 1 \\
\hline
\end{tabular}

WEBBER and PITMAN, 2008; WHITEHEAD, 2009). Linnaeus himself, in his original description (LINNAEUS, 1758), did not mention the presence of upper teeth.

Bennett (1836) was the first to question this statement. He observed that these small rudimentary teeth (less than $7 \mathrm{~cm}$ ) are not readily ascertained, because the whole series are not always apparent. However they may be seen upon the removal of soft parts of the jaw, even in young sperm whales. Flower (1869) also noticed this, and realized that the ventral surface of the maxilla has a strongly marked groove running longitudinally near the medial axis, evidently the remains of the dental groove where the upper teeth are placed.

Maxillary teeth of sperm whales are more common in studies that analyzed large samples (BOSCHMA, 1938; MATTHEWS, 1938; OMURA, 1950; CLARKE, 1956; CLARKE, AGUAYO and PALIZA, 1968; PIMPER, GOODALL, GIBBONS et al., 2008). Boschma (1938) and Matthews (1938) examined a large amount of upper teeth of specimens commercially caught in the Antarctic region. According to Matthews (1938), these teeth were present in $50 \%$ of his sample $(n=40)$ and they were bigger and more numerous in males than in females. Omura (1950) found upper teeth in $20 \%$ of the sperm whales caught in North Pacific.

Clarke (1956) and Clarke, Aguayo and Paliza (1968), studying the material collected in the Azores and Chile, respectively, also found maxillary teeth (erupted and unerupted) in several sperm whales and hypothesized that the frequency of upper teeth is higher in southern than northern specimens, something that need to be tested. Clarke (1956) was emphatic in asserting: "by an incision in the gum I have never failed to expose some maxillary teeth, even in whales where the upper jaw appears superficially toothless". Years later, Rice (1989) made this same statement. For Clarke (1956), Bennett (1836) was correct in maintaining that small maxillary teeth are a constant character in the sperm whale.

In Western South Atlantic, Pimper, Goodall, Gibbons et al. (2008) found 1-11 maxillary teeth in seven (17.5\%) of 40 sperm whales stranded in Tierra del Fuego, Argentina (Table 1). All of them were males.

Upper teeth are still present in physeterids from Oligocene through middle Miocene, like the oldest known physeterid Ferecetotherium kelloggi, from Azerbaijan (MCHEDLIDZE, 1984). Mchedlidze (2009) states that the great differences of the face and jaws (like those in the teeth) between early physeterids and Physeter macrocephalus suggest that the teutophagic specializations of the current species may not have been present in extinct relatives. According to the author, it is possible that Oligocene and Miocene physeterids were ichthyophagous (fish-eating), whereas modern sperm whales feed on deep-sea squid, and it is likely early physeterids were not deep-sea animals.

Therefore, the presence of maxillary teeth in sperm whales is a vestigial character, but is more frequent than previously thought. Upper teeth have been overlooked, and its real frequency can only be determined by an incision in the gum. This is important, since the study of maxillary teeth can provide information about evolution, functional morphology and age determination in sperm whales.

Acknowledgements: We are thankful to members of GEMMAR-PB for assistance during the necropsy. Thanks are also given to Telton Ramos for the support with the specimen's transportation and Newton Mota Gurgel Filho for the comments on the manuscript.

\section{References}

BENNETT, FD. Notes on the anatomy of spermaceti whale (Physeter macrocephalus). Proceedings of the Zoological Society of London, 1836, vol. 4 , p. 127

BEST, PB. CANHAM, PAS. and MACLEOD, N. Patterns of reproduction in sperm whales, Physeter macrocephalus. Report of the International Whaling Commission, 1984, vol. 6, p. 51-79.

BOSCHMA, H. On the teeth and other particulars of the sperm whale (Phvseter macrocephalus L.). Temminckia, 1938, vol. 3, p. 151-278.

CARWARDINE, M. Whales, dolphins and porpoises. New York: Dorling Kindersley Publishing, 2002. 256 p.

CASTELLO, HP. and PIÑERO, ME. Varamientos de cachalotes, Physeter catadon, en las costas del Atlântico del Brasil y La Argentina (Cetacea, Physeteridae). Physis (Rio de Janeiro, Brazil), 1974, vol. 86, p. 371-374

CLARKE, R. Sperm whales of the Azores. Discovery Reports, 1956, vol. 28 , p. 237-298.

CLARKE, R., AGUAYO, AL. and PALIZA, O. Sperm whales of the southeast Pacific. Part I: Introduction. Part II: Size range, external characters and teeth. Hvalradets Skrifter, 1968, vol. 51, p. 1-80.

FLOWER, WH. On the osteology of the cachalot or sperm whale (Physeter macrocephalus). The Transactions of the Zoological Society, 1869, vol. 6, p. 302-372, plates 55-61.

GERACI, JR. and LOUNSBURY, VJ. Marine mammals ashore: a field guide for strandings. Baltimore: National Aquarium in Baltimore, 2005. $371 \mathrm{p}$.

GIBBS, NJ. and KIRK, EJ. Erupted upper teeth in a male sperm whale, Physeter macrocephalus. New Zealand Journal of Marine and Freshwater Research, 2001, vol. 35, p. 325-327. 
JEFFERSON, TA., LEATHERWOOD, S. and WEBBER, MA. FAO species identification guide: marine mammals of the world. Rome: FAO, 1993. $320 \mathrm{p}$.

JEFFERSON, TA., WEBBER, MA. and PITMAN, RL. Marine mammals of the world: a comprehensive guide to their identification. New York: Academic Press, 2008. 573 p.

LINNAEUS, C. Systema naturae. 10th ed. Stockholm: Laurentii Salvii, 1758.

MATTHEWS, LH. The sperm whale, Physeter catodon. Discovery Reports, 1938, vol. 17, p. 93-168.

MCHEDLIDZE, GA. General features of the paleobiological evolution of Cetacea. Washington: Amerind Publication Corporation and Smithsonian Institution Libraries, 1984. 139 p.

MCHEDLIDZE, GA. Sperm whales evolution. In PERRIN, WF., WURSIG, B. and THEWISSEN, JGM. (Eds) Encyclopedia of marine mammals. New York: Academic Press, 2009. p. 1097-1098.

MEIRELles, ACO., MONTEIRO-NETO, C., MARTINS, A., COSTA, AF., BARROS, HM. and ALVES, MDO. Cetacean strandings on the coast of Ceará, north-eastern Brazil (1992-2005). Journal of the Marine Biological Association of the United Kingdom, 2009, vol. 89 , n. 5 , p. 1083-1090.

NISHIWAKI, M., HIBIYA, T. and OHSUMI, S. Age study of sperm whale based on reading of tooth laminations. The Scientific Reports of the Whales Research Institute, 1958, vol. 13, p. 135-153.

OMURA, H. Whales in the adjacent waters of Japan. The Scientific Reports of the Whales Research Institute, 1950, vol. 27, p. 1-13.

PIMPER, LE., GOODALL, RNP., GIBBONS, J., SOBRAL, AP., LOCKYER, CH. and PRADERI, R. A review of strandings of sperm whales from the Strait of Magellan to Cape Horn. In Proceeding of the Annual Meeting of the International Whaling Commission, 2008. Santiago de Chile: International Whaling Commission, 2008. 8 p. [Resumos].

RAMOS, RMA., SICILIANO, S., BOROBIA, M., ZERBINI, AN., PIZZORNO, JLA., FRAGOSO, AB., BRITO, JL Jr., AZEVEDO, AF., SIMÕES-LOPES, PCS. and SANTOS, MCO. A note on strandings and age of sperm whales (Physeter macrocephalus) on the Brazilian coast. The Journal of Cetacean Research and Management, 2001, vol. 3, n. 3, p. 321-327.

REEVES, RR., STEWART, BS., CLAPHAM, PJ. and POWELL, JA. National audubon society guide to marine mammals of world. New York: Knopf, 2002. 528 p.

RICE, DW. Sperm whale, Physeter macrocephalus Linnaeus 1758. In RIDGWAY, SH. and HARRISON, RJ. (Eds.). Handbook of marine mammals. London: Academic Press, 1989, vol. 4, p. 177-233.

SANTOS, MCO., SICILIANO, S., VICENTE, AFDC., ALVARENGA, FS., ZAMPIROLLI, É., SOUZA, SPD. and MARANHO, A. Cetacean records along São Paulo state coast, southeastern Brazil. Brazilian Journal of Oceanography, 2010, vol. 58, n. 2, p. 123-142.

TOLEDO, GAC. and LANGGUTH, A. Data on biology and exploitation of West Atlantic sperm whales, Physeter macrocephalus (Cetacea: Physeteridae) off the coast of Paraíba, Brazil. Zoologia, 2009 , vol. 26, n. 4 , p. 663-673.

WHITEHEAD, H. Sperm whale. In PERRIN, WF., WURSIG, B. and THEWISSEN, JGM. (Eds.). Encyclopedia of marine mammals. New York: Academic Press, 2009, p. 1091-1097.

Received November 5, 2014 Accepted November 18, 2015 